\title{
NORWIDOWSKI DRAMAT „TRANSFIGURACJI SPOŁECZNYCH”
}

Pojęciem „transfiguracji społecznych” Norwid posłużył się w wykładach O Juliuszu Słowackim. Jak pamiętamy, w wykładzie pierwszym przedstawił w chronologicznym zarysie problematykę społecznych obowiązków i ,socjalnej godności" poety. Dzieje kultury Izraela, Grecji, Rzymu i świata chrześcijańskiego dostarczyły prelegentowi argumentów na rzecz tezy o wyróżnionym, a nawet uprzywilejowanym stanowisku poety w życiu poszczególnych społeczeństw. Pomimo różnic historycznych i kulturowych, nieodmiennie pełnił on wedle Norwida zaszczytną rolę kapłana nadziei i jako taki integrował wszystkie kluczowe aspekty istnienia danej wspólnoty. Momentem przełomowym w pojmowaniu misji poety okazał się rozwój chrześcijaństwa: „Tajemnica tego bardzo jasna: kapłanowie nadziei nie mieli już co robić u Betlejemskiego żłobu" (PWsz VI, 209). Nadzieja została bowiem objawiona w Osobie Jezusa Chrystusa, co pociągnęło za sobą z konieczność zredefiniowania społecznego stanowiska poety. Norwid stawia zatem ważki problem: „Gdzież więc, mówię, ci kapłanowie odchodzą?! - oto odchodzą oni poza Niedzielę tej nadziei, oto odchodzą w dnie jej powszednie i robocze, albowiem dla człowieka pojedyńczego nadzieja jest już spełniona, ale dla człowieka zbiorowego, narodu i narodowości poczynającej się spełnienia nie było. Tam więc oni odchodzą, a przeto urzędu swego, k a płań stwa na dzi e i, nie składają [...], odchodzą witać całość, co jeszcze blasku Zbawicielowego nie doznała. Idą na pola, gdzie światłość Pańska nie zajaśniała jeszcze [...]" (PWsz VI, 409-410). W dalszej części wykładu Norwid kontynuuje tę myśl: „Jeżeli zatem powiedziałem, że poeci odchodzą w te strony, w których światło Zbawicielowej prawdy jeszcze nie świeciło, i idą przecież, nie tracąc właściwego im kapłaństwa nadziei, powiedziałem rzecz słuszną. Od tej chwili albowiem zajaśniała dla historii prawda nowa, że Ojczyna nie tylko w Chrześcijaństwie się zaczyna, ale zawsze jest 
ziemią obiecaną, że, ściślej mówiąc, pierwej była z i e m i ą o b i e c a n ą, potem społecznością obiecaną, a teraz mówię, że razem i ziemi, i s połeczności obiecanej wygląda się" (PWsz VI, 411-412). W na nowo zdefiniowanej misji poetów, współcześnie przede wszystkim kapłanów „społeczności obiecanej”, zasadniczą rolę odgrywa praca nad językiem, który powinien nadążać za przemianami społecznymi i przemianami świadomości, zainicjowanymi przez chrześcijaństwo: „Ten i ów lud albowiem, dziś polany wodą, dziś też policzony został w księgę i epopeję chrześcijańską, aleć języka lud żaden z dnia na dzień nie przemienia, języka mówię pasji uczuć i całej dramy życia, które się za przyjściem Chrześcijaństwa odmieniło [...]" (PWsz VI, 412). $\mathrm{W}$ tej sytuacji poeci mają do wypełnienia szczególnie ważną misję - stworzenia nie tylko nowego ,j ę z y k a fe no m e nó w", ale i nowego ,j ę zy k a tran sfiguracji społeczny ch" (PWsz VI, 412). Norwid postrzega to zadanie w kategoriach „strasznej próby”, gdyż od efektu działań poetów, jako zarazem twórców i dysponentów języka, a także artystycznych form prawdy, zależy przecież tak wiele... W ich gestii pozostaje bowiem podtrzymanie związku między językiem a współczesnym światem, co w konsekwencji oznacza zagwarantowanie warunków potrzebnych do rozwijania społecznej (samo)świadomości i społecznej komunikacji, które są fundamentem życia wspólnotowego. „Bez tych zaś języków nie możemy zaiste poznać epoki, w której się żyje, chyba że w liczbach kalendarzowych i matematycznych cyfrach, nieomylnych tam zwłaszcza, gdzie właśnie że już życia nie ma! Od tej to zaś chwili prace poetów na dwie się połacie rozłożyły: przeszłośc i i przytomności. Na jedną, aby rozwiązać mowę wieków w ustach Sfinksa, i na drugą, aby mowę chrześcijańską odtworzyć na nowo w chwili, gdy dąży do ubóstwienia formy samej, a przeto do spogańszczenia się, lubo częstokroć bezwłasnowolnie i bezsamowiednie" (PWsz VI, 413).

Pojęcie „transfiguracji społecznych” to moim zdaniem znaczący element metapoetyckiego dyskursu Norwida, zastosowany przezeń w wykładach zapewne również na prawach autokomentarza. Zwłaszcza w odniesieniu do twórczości dramatycznej poety przywołane pojęcie zdaje się ujawniać swą wagę i semantyczną głębię. Wszak o zmianie społecznej, następującej wraz z ekspansją chrześcijaństwa, Norwid mówi, posiłkując się nomenklaturą dramatyczną, jako o zmianie „całej dramy życia”, której powinna towarzyszyć zmiana w obrębie języka sztuki, oczywiście o ile twórca ma na uwadze swą socjalną misję i godność, o ile stawia sobie za cel postawę ,przytomności”, o ile pragnie być przewodnikiem na drodze do ziemi i społeczności obiecanej. To zaś - trudno tu o wątpliwości - cele samego Norwida.

Dramaturgia nie stanowi, jak wiadomo, szczególnie cenionego obszaru twórczości Norwida. Jego wizerunek jako pisarza był zawsze kształtowany przede 
wszystkim w oparciu o poezję liryczną i epicką, prozę artystyczną, publicystyczną i epistolarną. A jednak, co warto zawsze powtarzać, poeta uprawiał dramat przez całe swe życie, poczynając od Dobrych ludzi i Chwili myśli, datowanych na lata 1840-1841, a kończąc na Miłości-czystej u kąpieli morskich z około 1880 roku. Za tym gestem wierności krył się pewien zespół głębszych założeń. Nie da się ich sprowadzić do fascynacji czysto estetycznych określoną formą artystyczną, ani do działań postromantyka, nawiązującego do szczególnie wysokiej w epoce romantyzmu waloryzacji dramatu/poematu dramatycznego. Pamiętamy przecież krytyczne wobec romantycznej estetyki dramatu słowa: „dziś nie dość jest [...] tak nazwane fantastyczno-filozoficzne pisać dramata, częstotliwie raczej nie dokończone niźli głębokie" (DW VI, 110), i wciąż ponawiane wysiłki pisarza, by ukształtować nową, oryginalną formę dramatyczną, przekraczającą horyzont romantycznych wyobrażeń na ten temat. Norwid najwyraźniej dąży do wypracowania takiej postaci dramatu, która byłby głęboko zintegrowana z jego własnym programem poetyckim, również tym wyłożonym w prelekcjach $O J u$ liuszu Słowackim. Zakorzeniony w tradycji, dramat powinien być więc twórczą odpowiedzią na wyzwania czasu, permanentnie przeobrażającego „dramę życia”, a w związku z tym wymaga stworzenia i ciągłego odnawiania języka ,transfiguracji społecznych".

Forma dramatyczna wydała się Norwidowi wyjątkowo podatna na tego rodzaju operacje twórcze. W rozumieniu pisarza dramat (wespół z teatrem) pozostaje bowiem od wieków w ścisłym związku z życiem społecznym i jego historycznymi przemianami, co poświadcza niezbyt rozległa, ale wielowątkowa refleksja Norwida na temat dorobku dramatyczno-teatralnego ludzkości. Wystarczy w tej perspektywie problemowej ponowić w pierwszej kolejności lekturę szkicu Widowiska w ogóle uważane, by dostrzec, jak istotny jest to dla jego autora aspekt dramatu. Trzeba oczywiście uwzględnić fakt, iż mamy do czynienia $z$ tekstem sporządzonym przez Norwida w oparciu o istniejący stan wiedzy ${ }^{1}$, a zatem wywód nie jest w pełni oryginalny, jednak rozłożenie akcentów interpretacyjnych z pewnością pochodzi od twórcy szkicu i dobrze oddaje jego punkt widzenia. Zwraca uwagę konsekwentne sytuowanie początków sztuki dramatycznej w szeroko nakreślonym kontekście religijno-społecznym. To obrzędy religijne i życie zbiorowe stanowiły w starożytnej Grecji i Rzymie źródła teatralnych widowisk: „Gry publiczne na Cyrku były więcej przeznaczone dla

${ }^{1}$ Zagraniczne źródła, z których Norwid mógł korzystać w trakcie pracy nad swą rozprawką, nadal pozostają nie zidentyfikowane. Wiadomo jednak, że nieobce mu były również polskie prace na temat historii teatru, np. Teatr starożytny w Polsce Kazimierza Władysława WóJCickiego (Warszawa 1841). 
ogółu zebranej publiczności na dzień święta jakiego [...], dla zajęcia masy zgromadzonej na dzień uroczystości” (PWsz VI, 388). Natomiast: „S c e n a - czyli g r a właściwa - ta miała bliższy związek z religijnymi obrzędami” (PWsz VI, 388), jej celem był religijnie pojmowany kult bóstw i bohaterów. $Z$ tego właśnie podłoża wyłonił się teatr starożytny jako zjawisko estetyczne, oczywiście zachowujące pamięć pierwotnego związku z obrzędem: „g r a sceniczna” powstała bowiem ,z c hó ró w obrzędowych i z solo bóstw albo bohaterów, czyli pół-bogów - powstała więc z pieśni czytanej, śpiewanej i tańczonej około ołtarzy, które przed schodami świątyni stały i na których paliły się ofiary" (PWsz VI, 389). Gdy jednak mowa o kształtowaniu się kolejnych form dramatu, to Norwid mocno akcentuje ich społeczne zakorzenienie, bo „dramę”, której synonimem jest „akcja, czynienie, życie, działanie”, wynalazł, jak twierdzi: „duch ogółu społeczeństwa, potrzeba wewnętrzna" (PWsz VI, 390). Z kolei chóry, będące obok protagonisty (bywał nim sam poeta, co dla Norwida istotne ${ }^{2}$ ) nieodłącznym elementem dramatu, choć powstały z obrzędowego tańca, to ostatecznie „wyrażały jakoby objaśnicieli i nauczycieli sensu moralnego rzeczy reprezentowanej - było to jakby pomiędzy publicznością a sceną ustanowione kapłaństwo publiczności” (PWsz VI, 391).

W świecie chrześcijańskim Norwid dostrzega w rozwoju teatru i dramatu zjawiska analogiczne. Pisze o kontynuowaniu formy rzymskich igrzysk, które podlegają stopniowej degeneracji, aż wreszcie stają się krwawą areną męczeństwa chrześcijan, co ostatecznie zamyka ich historię. Odnotowuje rolę trubadurów, „którzy w śpiewy swoje wprowadzili pewien rodzaj akcji i deklamacji”. Tym sposobem „na nowo mogłaby była sztuka rozpoczynać od solo poety i c h ó ró w”, gdyby trubadurowie nie skończyli „na improwizacjach smaku zepsutego”, gdyby nie ograniczyli się do „dźwięcznej gimnastyki wyrazów”, czyli do poezji czysto wirtuozowskiej (PWsz VI, 392). I wreszcie, co najważniejsze, pisarz ukazuje, jak ponownie wokół obrzędów religijnych i pewnych zjawisk życia społecznego rodzą się formy dramatu chrześcijańskiego: misteria, tzn. rodzaj dramy mistycznej czy tragedii chrześcijańskiej, których wzorem i paradygmatem jest sceniczna reprezentacja Męki Pańskiej, oraz komedia, czyli „widowisko obyczajów i ich zdrożności” (PWsz VI, 394), mające źródło w środowisku prawniczym i nawiązujące do sytuacji sądu nad ludzkimi przywarami, uchybieniami, przewinami. I misterium, i komedia były zdaniem Norwida nośnikami tej samej prawdy chrześcijańskiej, jednak inny był sposób jej przekazu: pierwsza z form ukazywała - ide-

${ }^{2}$ O roli podmiotu autorskiego w dramaturgii Norwida pisałam w książce: Dramat i romantyczne „Ja”. Studium podmiotowości w dramaturgii polskiej doby romantyzmu, Kraków 2002 (rozdz. Norwidowski dramat wieloperspektywiczny). 
ał, a druga - jego realizację w rzeczywistości społecznej, unaoczniając przy tym obyczajową stronę życia ${ }^{3}$.

Autor Widowisk w ogóle uważanych uwypukla w swym wywodzie historyczny aspekt istnienia teatru i dramatu, postrzegając je jako część dziejów kultury, w których obowiązuje Vikiański model rozwoju: ,Jest to koło, które się samo przeciwnymi końcami obrębu zawiązuje i nowe zeń wywija się" (PWsz VI, 391) ${ }^{4}$. A zatem w dziejach sztuki dramatycznej nic nie powtarza się mechanicznie, bo „powtarza się zawsze z jakiejś strony w p ot ę d z e w y ż s z e j” (PWsz VI, 392). Norwid dostrzega w historii widowisk znaczenie i ciągłości, i zmiany zarazem. $\mathrm{Z}$ jednej strony potwierdza kumulatywny charakter dokonań dramatyczno-teatralnych: „To więc, co dzisiejszą d ra mę składa, to są całe e poki historii teatru" (PWsz VI, 390), ale z drugiej akcentuje konieczność przeobrażeń form dramatu, z uwagi na bieżący tok życia społecznego. Tak więc: „Shakespeare, Molière to są jeszcze odcienia tejże samej rzeczy, lubo wedle cywilizacji, i jej potrzeb zmodyfikowane" (PWsz VI, 391). Nie ma wątpliwości, że sam jako dramaturg postępuje podobnie - podtrzymuje związek ze źródłami i różnymi historycznymi postaciami dramatu, a jednocześnie postrzega go przez pryzmat procesu cywilizacyjnego i „transfiguracji społecznych”, uznając, że jest on formą ich scenicznej reprezentacji, odbywającej się w obecności patrzących na nią widzów, co jednoznacznie sugeruje termin „widowisko".

Również wśród licznych uwag na temat dramatu zapełniających karty Białych kwiatów znajdziemy stwierdzenia odnośnie do społecznej natury tej formy artystycznej. Jak pamiętamy, Norwid konstatuje tu nieobecność pełnego, ,prawdziwego-dramatu” (DW VII, 61) - nie ma go nigdzie, ani u nas, ani na świecie: „Teatr i drama współczesna [...] krytyki nie wytrzymują i umarłymi są" (DW VII, 66). Jedną z przyczyn tego kryzysu, w który popadła współczesna pisarzowi twórczość dramatyczno-teatralna, jest jego zdaniem zatrata poczucia znaczenia ciszy, jej fundamentalnej roli w kreowaniu sytuacji dramatycznych. Jednak przykład przywołany przez autora eseju na potwierdzenie tej funkcji ciszy odsłania jedno-

${ }^{3}$ Rozróżnienie to było efektywnie wykorzystywane przez Irenę Sławińską w jej wszechstronnych badaniach nad dramaturgią Norwida, zwieńczonych koncepcją Norwidowskiego dramatu jako wielowariantowej „,chrześcijańskiej dramy”. Zob. I. SŁAwIŃSKA, ,, Chrześcijańska drama” Norwi$d a$, ,Studia Norwidiana” 3-4: 1985-1986.

${ }^{4}$ Nawiązania do myśli Vico można odnaleźć i w innych obszarach twórczości Norwida. Zob. E. FeliKsiaK, Norwid i Vico, „Przegląd Humanistyczny” 1968, nr 3.

${ }_{5}^{5}$ Termin jest notowany przez słownik Lindego i objaśniany m. in. jako „spektakl, zjawienie oczom”. Należy podkreślić, że ten zakres znaczeniowy słowa „widowisko” okaże się dla myśli Norwida ważny, zwłaszcza tam, gdzie celem pisarza będzie zaakcentowanie poznawczej i moralnej roli dramatu i teatru. 
cześnie miejsce teatru w życiu społecznym. Historia zabójstwa ministra Rossiego i jego wymowna nieobecność w loży na operowym przedstawieniu Macbetha staje się dla Norwida okazją do analizy zachowań teatralnej publiczności (,,dlatego się udałem do teatru, aby publiczność widzieć" - podkreśla narrator; DW VII, 66), do spojrzenia na teatr przez pryzmat niezwykłej interakcji obejmującej scenę i widownię: „W miarę [...] jak opera przez treść swą w dramę i tragedię przechodzić z czasem zaczynała, pusta loża ministra Rossi, nie oświecona jako inne (iż familijna była), ciemnopurpurowe, aksamitne wnętrze swoje ku światłu, jak wielka rana, odmykając, uprzedziła wrażeniem magiczną oną Shakespeare'owskiej tragedii chwilę, kiedy cień zasztyletowanego Banka na pustym krześle przy uczcie teatralnej zasiadać ma... I poczęło się grać pomiędzy publicznością a sceną to, co Shakespeare w Hamlecie obmyślił był, aby zagrać tragedię na dworze, scenę na scenie dając..." (DW VII, 67).

Opisana przez Norwida sytuacja oczywiście wykracza poza granice konkretnego wydarzenia, w istocie parabolicznie odsłania kilka zasadniczych aspektów pojmowania teatru. Przede wszystkim ukazuje go jako część sfery publicznej, uznawanej przez pisarza za niezbywalną formę życia wspólnotowego. Teatr to forum publicum, miejsce, w którym sprawy publiczne podlegają interpretacji - tu bowiem dokonuje się symboliczne reprezentowanie realnego społecznego świata. Co więcej, właściwy spektakl przekracza granicę sceny i ostatecznie rozgrywa się pomiędzy nią a widownią, co czyni tę ostatnią współbohaterką przedstawienia. W efekcie zbiorowe zachowania, akty percepcji i rozumienia właściwe publiczności nabierają symbolicznego znaczenia. Ponadto przenikanie się realiów życia społeczno-politycznego (zabójstwo ministra) i akcji dramatu Shakespreare'a (zabójstwo Banka) każe widzieć w teatrze nie tylko komentatora bieżących wydarzeń, ale też organ ich moralnego osądu, co sugeruje przede wszystkim aluzja do sceny teatru w teatrze, w której Hamlet pochwytuje w swą ,pułapkę na myszy" ludzkie sumienia. Nawiązanie do Hamleta unaocznia przy tym ważny aspekt wyobraźni i świadomości Norwida, a mianowicie skłonność do interpretowania rzeczywistości przez pryzmat metafory theatrum mundi (zarówno w wersji Dei theatrum mundi, jak i hominis theatrum mundi). Życie społeczne poeta nierzadko przedstawia więc w kategoriach teatru, a w człowieku chętnie widzi aktora odgrywającego na teatralnej scenie dramat swego indywidualnego losu i historii cywilizacji ${ }^{6}$.

Powyższy sposób myślenia o dramacie znajduje kontynuację we Wstępie do Pierścienia Wielkiej-Damy. Tu również dramat nie jest formą autonomiczną względem praktyki życiowej oraz religijno-moralnych norm regulujących funkcjonowa-

${ }^{6}$ Zob. A. DuNAJSKI, Chrześcijańska interpretacja dziejów w pismach Cypriana Norwida, Lublin 1985, s. 111-121; S. ŚwiONTEK, Norwidowski teatr świata, Łódź 1985. 
nie społeczności. Adresowany jest w pierwszej kolejności do odbiorcy zbiorowego („należy nie być osobistym w przyjmowaniu wrażeń scenicznych”; DW VI, 110), który za jego pośrednictwem może uczestniczyć w „wyrabianiu się prawdy”, a nawet zbliżyć się do prawdy bezwzględnej i w jej świetle dokonać aktu samopoznania i moralnej autorefleksji. Proponowana przez Norwida „Tragedia-Biata” jest przeznaczona do „budującego działania wobec chrześcijańskiego społeczeństwa”, ma być „periodem obejrzenia-się-społeczności całej, i z jej najsłuszniejszej wyżyny, na sama siebie”, tu bowiem „cywilizacyjna-całość-społeczna, jakoby ogólnego sumienia zwrotem, pogląda na się" (DW VI, 110). Ważne wydaje się operowanie przez Norwida w jego metadramatycznym dyskursie pojęciem ,cywilizacyjnej-całościspołecznej”, które pozwala autorowi wznieść postulowany przezeń dramat w rejony „wielkiego Serio”, na wyżyny uniwersalnej paraboli, a oddala go od rozwiązań charakterystycznych np. dla komedii buffo (w tym Fredrowskiej), gdzie „warstwa jedna społeczna, przygladając się drugiej, postrzega ona w jej śmiesznościach" (DW VI, 110). Drugie niezwykle ważne określenie padające w analizowanych rozważaniach Norwida, a ściśle wiążące dramat z życiem społeczności, to termin „budowanie", mający tu sens zarówno estetyczny (budowanie, czyli tworzenie, kreacja nowych, oryginalnych form dramatu), jak i poznawczo-moralny. Czytamy: „Co do moralnego zadania, mniemam, iż strona święta, budująca, religijna starożytnej tragedii nie ustała wcale ani może ustać, ale że gdzie indziej pośród utworów dramatycznych główne obrała miejsce swoje" (DW VI, 110). Tym miejscem jest właśnie tragedia-biała, która przy użyciu innych niż w starożytności środków artystycznych zachowuje jednak zasadniczy cel dawnego dramatu, jakim było moralne ,,budowanie", formowanie jego odbiorców, a inaczej mówiąc, jakim było jego paideutyczne oddziaływanie. Dramat i teatr jako istotny czynnik społecznej paidei to idea Norwidowi bardzo bliska, choćby dlatego, że obecna w niezwykle ważnej dla poety tradycji filozoficznej - w myśli jego intelektualnych przewodników: Sokratesa, Platona, filozofów epoki hellenistycznej ${ }^{8}$. Także i współcześnie paideia może być wedle Norwida realizowana poprzez widowiska dramatyczno-teatralne: „Aliści i to jeszcze łatwiej się sprawuje we społecznościach, w których, do ważenia i używania praw$d y$ nawyknąwszy, rozeznawać na pierwszy oka rzut umieją kapitalną różnicę, jaka trwa pomiędzy naśladownictwem a zbudowaniem. Drugie, będąc obowiązującym i w ład-postępu wchodzącym, a przeto początkującemu pożądanym i pomocnym,

${ }^{7}$ Nawiązuję tu do słów padających w czwartym wykładzie O Juliuszu Słowackim, w którym Norwid łączy kategorię „dramatu życia” z kategorią paraboli: „parabole mają to do siebie, że nie tylko prawdy przedstawiają, ale i dramat życia prawdę wyrabiający” (PWsz VI, 433).

${ }^{8}$ Krąg intelektualnych i literackich źródeł Norwidowskiej metaforyki teatralnej naszkicował Sławomir ŚWIONTEK (zob. tegoż, Norwidowski teatr, s. 51-81). 
gdy pierwsze, to jest naśladownictwo, przeciwnym będąc samej nawet ducha-naturze, przeciąża zarazem naśladowanego i naśladującego w konieczny wprowadza obłęd. Zaś dostrzegać daje się, że im mniej jakie społeczeństwo jest żywe, tym nie jaśniejsze ma ono pojęcie o różnicy pomiędzy zbudowaniem się i naśladowaniem!" (DW VI, 111-112). A zatem skuteczność teatralnej paidei wymaga swoistych dyspozycji po stronie odbiorców spektaklu: poznawczej i egzystencjalnej gotowości do przyjęcia prawdy oraz gotowości do jej praktykowania, a nie powierzchownego naśladowania ${ }^{9}$. Od tego m. in., jak sugeruje Norwid, zależy jakość życia społecznego, partycypacja społeczeństw w cywilizacyjnym postępie i duchowym wymiarze rzeczywistości, a ostatecznie również istnienie danej zbiorowości. Społeczeństwo martwe, którego obrazem Norwid niejednokrotnie posługuje się w swej publicystyce i epistolografii, nie potrafiąc „się budować”, zrywa więź ze źródłem istnienia, pogrąża się w aktach naśladowania, traci autentyczność i ciągłość własnego bytu, trwoni wspólnotową integralność na rzecz rozmaitych indywidualistycznych zachowań, które nie znajdują aprobaty pisarza również w słowie wstępnym do Pierścienia...: „A uszczerbek z tego wielki bywa... Bowiem skoro nie umieją się budować, tedy muszą co niejaki period żądać indywidualności i od onej jeszcze wszystkiego $i$ wszelakiego początkowania wymagając, a z żadnego statecznej korzyści nie odnoszac ... aż nareszcie i same one źródło niweczą" (DW VI, 112).

Z powyższą problematyką powiązać trzeba też kwestię podnoszoną przez Norwida już w Biatych kwiatach, a mianowicie braku w literaturze polskiej ,kobiet istotnych i całych" (DW VI, 112), bez których trudno o dobry dramat. Dla pisarza nie jest to, jak sadzę, problem natury estetycznej, lecz zagadnienie o charakterze przede wszystkim społecznym - we Wstępie do Pierścienia Wielkiej-Da$m y$ Norwid określa je jako ,głębokie dla psychologii społecznej pytanie” (DW VI, 112). Kobieta, przypomnijmy myśl twórcy Pierścienia..., ma do spełnienia szczególną misję w życiu każdego społeczeństwa. Jest ona bowiem, jak pisał w liście do Marii Trębickiej: ,j e d y n y m re a lnym wę zł e m między p ojedyńc zą o s obą a zbi orową" (PWsz VIII, 288). A będąc „najżywszym węzłem pomiędzy samotnym $\mathrm{J}$ a a publicznym $\mathrm{M}$ y, stawa się pierwszą kapłanką naturalnie immolującą egoizm i dającą ugruntowanie zbiorowemu ciału społecznemu" (PWsz VI, 653). Kobieta, świadoma tego, że ,u-osobia całokształt społeczności"(PWsz IX, 49), może mieć w opinii Norwida pozytywny wpływ na życie zbiorowe, czyniąc je życiem prawdziwie wspólnotowym. W kontekście zacytowanych uwag zrozumiała staje się zatem walka pisarza o odpowiednią postać kobiecą w dramacie. Również od tego zawisła bowiem społeczna misja teatru.

${ }^{9}$ Kwestia praktykowania prawdy to częsty wątek epistemologicznej refleksji Norwida, znajdujący dobitną rekapitulację w eseju Milczenie. 
Oczywiście w refleksji Norwida formułowane są też warunki stricte estetyczne, które powinny być spełnione, aby twórczość dramatyczno-teatralna mogła osiągnąć swe szczytne społeczne cele. Tu warto powrócić do wyodrębnionego powyżej znaczenia Norwidowskiego terminu „budowanie” jako synonimu tworzenia nowych form dramatu. Bez innowacyjności w dziedzinie gatunków dramatycznych, bez umiejętności w zakresie subtelnego kreowania dialogu w dramacie na wzór „wykwintnego dialogu potocznego" (DW VI, 111), bez dbałości o kształtowanie dramatu jako ,form mówienia" (DW VI, 110), jako partytury dla mowy aktora (wygłaszanej lub czytanej) dramaturgia nie jest w stanie podążać za społecznymi przemianami i rzetelnie odzwierciedlać procesu przemijania pewnych form świata i rodzenia się form nowych ${ }^{10}$. We Wstępie poprzedzającym Pierścień... Norwid przyrównuje dążenie do uzyskania efektu przystawalności dramatu i świata do pracy krawca: godzi się bowiem, aby „w dnie stanowczej próby wszyscy dramaturgowie znamienici, przytomni bywając onemu, że tak się wyrażę, przymierzeniu nowo uzupetnionej sukni, nie pozostawiali przechodzących dzieł na scenę bez tych a owych niewielkich ostatecznych zlepszeń - i że częstotliwie coś o mało zdłużyć lub niewiele uskąpić, coś wypadało domocnić lub ulżyć. Ostatecznej tej dla autora, a dla aktorów pierwszej pracy świadomi są wszędzie, gdzie, że tak znowu wyrażę się, nie chodziło się arcydtugo w szatach pierwej dla kogo innego utrafionych!..." (DW VI, 111).

Jak wiemy, sam taką właśnie pracę nad udoskonaleniem form dramatycznych prowadził przez całe życie, z pewnością powodowany chęcią wykreowania dramatu, który byłby propozycją adekwatną wobec aktualnej sytuacji cywilizacyjnej. W swych poszukiwaniach twórczych odważnie przekraczał więc istniejący repertuar gatunków dramatycznych, równocześnie destruując formy anachroniczne i na ich podstawie kreując nowe. O skali tego przedsięwzięcia informują kwalifikacje gatunkowe pojawiające się w podtytułach dramatów lub w autorskich komentarzach ${ }^{11}$. Potwierdzają one, że zdolnością do przekształceń i resemantyzacji genologicznych

${ }^{10}$ W wykładach O Juliuszu Słowackim Norwid dochodzi do wniosku, iż to samo życie, kształtując swe formy, dostarcza form sztuce: ,aby życie w siebie wglądało, potrzeba przecież, aby za sobą pozostawiło formy swoje”. Dalej zaś, odwołując się do metafory teatralnej, stwierdza: „Cały przecież ogół naszego bytu i form będzie na scenie kiedyś, jak widzimy wiek zeszły: ale pozostanie zeń to wszystko, co żywotne, co wieczne" (PWsz VI, 462).

${ }^{11}$ Przywołajmy te oryginalne określenia: Zwolon to „monologia”, Wanda - ,rzecz w obrazach sześciu”, Słodycz - „tragedia w jednej scenie”, Krytyka - ,poema dramatyczne w trzech obrazach”, Aktor - „komediodrama”, Hrabina Palmyra oraz Dobrzy ludzie - „komedia serio”, Tyrtej - „tragedia fantastyczna”, Za kulisami oraz Chwila myśli - „fantazja”, Pierścień Wielkiej-Damy - „,biała-tragedia”, Kleopatra i Cezar - ,tragedia historyczna ściśle w równi do grania, jako i do odczytów napisana: $\mathrm{z}$ uwydatnieniem gestów dramatycznych i onych ciągu". 
Norwid wykazywał się w odniesieniu do wszystkich uprawianych przez siebie form dramatu, jednak w stopniu najwyższym ujawnił te predylekcje na terytorium tragedii $^{12}$, przy czym zasadniczy cel swej formalnej kreatywności w tej dziedzinie opisał we Wstępie do Pierścienia Wielkiej-Damy. Utwór ten, przykład nie spotykanej dotychczas formy dramatycznej (w literaturze takiej ,rzeczy jeszcze nie ma”; DW VI, 110), stanowi wedle autora „nowy tragedii rodzaj”, oparty na twórczej kontaminacji poetyki przeobrażonej już komedii (,komedia-wysoka”) z poetyką zmodyfikowanej tragedii (,tragedia-biała”). W ten sposób tragedia zostaje odnowiona - uzyskuje nową „szatę”, ale właśnie dzięki temu może nadal spełniać swą odwieczną funkcję - ,świętą, budującą, religijną", i- dodajmy - paideutyczną ${ }^{13}$.

Jak widać, w swej refleksji o historii, funkcjach i formach dramatu Norwid wypowiada szereg uwag odnośnie do dramatyczno-teatralnego języka „transfiguracji społecznych”. Jego myśl wyraźnie zmierza w stronę rozumienia dramatu w optyce kategorii estetycznych i ponadestetycznych jednocześnie. Przedmiotem zainteresowań pisarza jest zarazem dramat artystyczny, sceniczny, będący częścią kultury ekspresywnej, jak i dramat społeczny - dramat ludzkich działań, interakcji, procesów zachodzących w społeczeństwie, międzykulturowych konfrontacji i analogii - pojmowany jako konstytutywny element społecznego doświadczenia i potencjalny przedmiot interpretacji o charakterze antropologiczno-socjologicznym, opisujacych zjawiska społeczne w języku dramatu ${ }^{14}$. W związku z tym bliska intencjom Norwida wydaje się kategoria widowiska kulturowego, która w dynamicznie rozwijających się dziś badaniach nad tym fenomenem uzyskała następujące objaśnienie: „widowisko kulturowe to coś więcej niż rozrywka, więcej niż dydaktyczny lub perswazyjny przekaz, więcej niż katartyczne odreagowanie: to chwile, w których jako kultura bądź jako społeczeństwo podejmujemy refleksję nad samymi sobą i definiujemy samych siebie, odgrywamy nasze wspólne mity i naszą historię, przedstawiamy alternatywne wersje samych

12 Norwidowskiej koncepcji tragedii poświęciłam odrębny artykuł: Między starożytnościa a wspótczesnością. Formy tragedii w twórczości Cypriana Norwida, w: Dtugie trwanie. Różne oblicza klasycyzmu, pod red. R. Dąbrowskiego i B. Doparta, Kraków 2011, s. 175-187.

${ }^{13}$ Zapowiedź tego sposobu pojmowania tragedii znajdziemy w przedmowie do Krakusa: „Co do mnie mniemam, iż tragedia jest to uwidomienie fatalności historycznej albo socjalnej narodowi albo wiekowi jakowemu wyłacznie właściwej - a przeto, zważając ją tak, to jest jako pomocniczą w postępie moralności i prawdy pracę, nie dziwi mię bynajmniej, iż tragedia mieć mogła i musiała powagę nieledwie obrządkową" (DW V, 161).

${ }^{14}$ Podejście dramaturgiczne w naukach społecznych ma źródło w dziewiętnastowiecznej filozofii pragmatyzmu, a rozwijane było następnie przez tak wybitnych myślicieli, jak np. George Mead, Herbert Blumer, Anselm Strauss, Erving Goffmann, tworzących nurt interakcjonizmu symbolicznego. Zob. E. HAŁAS, Interakcjonizm symboliczny. Społeczny kontekst znaczeń, Warszawa 2006. 
siebie czy też zmieniamy się pod pewnymi względami, by pod innymi pozostawać tacy sami" ${ }^{15}$. Wedle innej definicji widowisko to kultura „w działaniu”, sposób podtrzymywania kompetencji i tradycji kulturowej: „Widowisko jest nie tylko czymś twórczym, realizowanym, ustanawianym czy nawet czymś transcendentnym względem zwykłego toku wydarzeń; widowisko często stanowi warunek przetrwania tradycji jako takiej" ${ }^{\prime 1}$. W tej z konieczności syntetycznej charakterystyce widowiska kulturowego nie może zabraknąć jeszcze jednej jego cechy, często rozważanej przez badaczy, a mianowicie refleksywności, oznaczającej za-

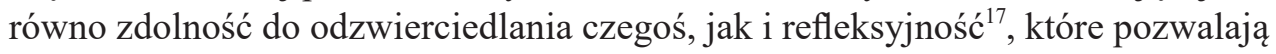
widzieć w nim rodzaj społecznego metakomentarza. Refleksywność jest w teorii widowisk uznawana za umiejętność dystansowania się od własnych subiektywnych doświadczeń, przejmowania obcego punktu widzenia i stawania się przedmiotem samooglądu: „to zdolność do tego, by stać się publicznością dla samego siebie" ${ }^{18}$ i dzięki temu osiągnąć stan samoświadomości, a nawet świadomości samoświadomości. Ujrzenie własnej rzeczywistości kulturowej w świetle widowisk jest według teoretyków tego zjawiska okolicznością niezbędną dla prawidłowego funkcjonowania zbiorowości - w prawdzie o samej sobie.

Formą widowiska kulturowego, jego podstawowym materiałem i strukturalnym źródłem jest wspomniany już dramat społeczny. Victor Turner, twórca uniwersalnego modelu dramatu społecznego, wyjaśniał za jego pośrednictwem dynamikę zmian społecznych, zaburzeń i konfliktów, przebiegających w różnych kulturach i na różnych etapach ich rozwoju wedle, jak sądził, stałego scenariusza: naruszenie ładu, kryzys, przywrócenie równowagi, efekt działań (ponowne ustanowienie pokoju lub schizma) ${ }^{19}$. Co ważne, w swym modelu widowiska kulturo-

15 J. J. MacAloon, Wstęp: widowiska kulturowe, teoria kultury, w: Rytuat, dramat, święto, spektakl. Wstęp do teorii widowiska kulturowego, red. J. J. MacAloon, przeł. K. PrzyłuskaUrbanowicz, Warszawa 2009, s. 12. Zob. też: Antropologia widowisk. Zagadnienia i wybór tekstów, oprac. A. Chałupnik, W. Dudzik, M. Kanabrodzki, L. Kolankiewicz, wstęp i red. L. Kolankiewicz, Warszawa 2005.

16 Tamże, s. 24.

17 Zob. np.: R. SCHECHNER, Collective Reflexivity: Restoration of Behavior, w: A Crack in the Mirror: Reflexive Perspectives in Anthropology, eds. B. Myerhoff, J. Ruby, Philadelphia 1982; B. A. BABCOCK, Reflexivity: Definitions and Discriminations, w: Signs about Signs. The Semiotics of Self-References, ed. B. A. Babcock, New York 1980.

18 J. J. MACAloOn, s. 30; V. TuRner, Liminalność i gatunki performatywne, w: Rytuat, dramat, święto, spektakl. Wstęp do teorii widowiska kulturowego, s. 40, 46-47.

19 Zob. V. TuRner, Schism and Continuity in an African Society, Manchester 1957; V. TURNER, Gry społeczne, pola i metafory. Symboliczne działanie w społeczeństwie, przeł. W. Usakiewicz, Kraków 2005. 
wego odwoływał się do dramatu scenicznego jako sposobu uświadamiania sobie dramatu społecznego ${ }^{20}$, a także do teorii rytuału, o czym będzie jeszcze mowa.

Mając na uwadze zarysowany powyżej kontekst, warto przyjrzeć się światom przedstawionym w dramaturgii Norwida. Większość jego dramatów unaocznia przecież sytuację przemiany społecznej - ta jest w nich czynnikiem akcji i głównym jej wątkiem, wokół którego koncentruje się problematyka i przesłanie poszczególnych dzieł. To znamienne, że Norwid tak konsekwentnie wybiera jako moment dramatycznego dziania się sytuację zmiany, przełomu, przejścia z jednej formy życia społecznego w drugą, choć oczywiście proponuje różne estetyczne (była o tym mowa) i antropologiczne perspektywy oglądu tej sytuacji. Odwołuje się zarówno do studiów jednostkowych przypadków, jak i do panoramicznych, często porównawczych ujęć życia zbiorowego, gdyż przemianę społeczną chce postrzegać wieloperspektywicznie: od strony doświadczenia konkretnego człowieka - protagonistów dramatu i od strony dynamiki dziejowego procesu, konfrontacji etosów kulturowych i formacji cywilizacyjnych. O przykłady potwierdzające tę tezę nietrudno, dlatego ograniczę się do przykładów wybranych.

Na pewno należy przywołać w związku z tym pierwszy obszerniejszy dramat Norwida, czyli Zwolona. W autorskich komentarzach dzieło to zostało bowiem bardzo mocno powiązane z konkretną sytuacją społecznego przełomu, czyli z wydarzeniami Wiosny Ludów. I choć wydarzenia te nie podlegają tu bezpośredniemu dramatycznemu przedstawieniu, to jednak Norwid niejednokrotnie akcentuje znaczenie powyższego kontekstu, pisząc o swym utworze jako stworzonym ,na zaraniu ostatniego europejskiego ruchu” (PWsz VIII, s. 101), łącząc je

20 „Twierdzę, że dramaty społeczne są surowym materiałem, z którego dopiero tworzony jest teatr - w miarę jak rosną rozmiary i złożoność społeczeństw - i dzięki któremu teatr nieustannie się odradza. Sądzę też, że forma dramatu społecznego jest w swej istocie uniwersalna, choć może znajdować rozmaite kulturowe rozwinięcia w poszczególnych społecznościach" (V. TURNER, Liminalność i gatunki performatywne, s. 48-49). W innym miejscu kwestia wzajemnych relacji dramatu społecznego i dramatu scenicznego uzyskuje bardziej precyzyjne wyjaśnienie: „Otóż jawny dramat społeczny zasila u t a j o n y obszar dramatu scenicznego; forma pierwszego z nich, właściwa danej kulturze w danym miejscu i czasie [...] wpływa nie tylko na formę, ale i na treść dramatu scenicznego, w którym jak w ruchomym lub magicznym zwierciadle odbija się dramat społeczny. Dramat sceniczny, jeśli jest czymś więcej niż rozrywką [...], stanowi metakomentarz - jawny lub ukryty, zamierzony lub przypadkowy - do głównych dramatów społecznych swej epoki [...]. Nie dość na tym, przesłanie i retoryka dramatu scenicznego ze swej strony dostarczają pożywki utajonej strukturze dramatu społecznego, co często tłumaczy jego podatność na rytualizację. Życie staje się zwierciadłem, w którym odbija się sztuka, a żywi ludzie zaczynają o d g r y w a ć własne życie, ponieważ dramat sceniczny dostarcza protagonistom dramatu społecznego [...] najbardziej charakterystycznych opinii, wyobrażeń, środków stylistycznych i perspektyw ideologicznych" (V. TuRnER, Teatr w codzienności, codzienność w teatrze, przeł. P. Skurowski, „Dialog” 1988, nr 9). 
z niedawnymi działaniami politycznymi i emigracją: „A wszystko słowem prędkim - bo pisano / Przy łunach, które tu i ówdzie błysły”; „Jest to więc dramat wcale emigrancki" (DW V, 35). Świat przedstawiony Zwolona, będący parabolą historycznego doświadczenia ${ }^{21}$, cechuje chaotyczność, dysharmonijność, fragmentowość, znamienna dla obrazowania czasów zamętu i przemiany. Harold skomentuje rzeczywistość przedstawioną ironicznie: „Wszystko dziwnie się plecie / W tego państwa tu świecie / A kto rzecz by spisował / I połączyć chciał - pewno / Ciąg by gorzej popsował" (DW V, 86), zaś sam Norwid w liście do Lenartowicza ujrzy „wśród tego pękającego się świata” dramat młodego pokolenia (PWsz $\mathrm{V}, 102)$. Rozpad spójnej wizji rzeczywistości znajdzie w Zwolonie szerokie odzwierciedlenie na poziomie świadomości podmiotu dzieła, autorskich wyborów estetycznych oraz, co dla nas szczególnie ważne, prezentowanych form życia społecznego i idei o społecznym rezonansie: despotyczne rządy tyrana vs. dążenie do wolności; konspiracja, rewolucja, idea zemsty vs. chrześcijańska idea zwolenia, wydobyta z Bogurodzicy, rozwijana w wypowiedziach Zwolona i widzeniu Pacholęcia, a wskazująca na powinność naśladowania Zbawiciela.

W Wandzie i Krakusie akcja rozgrywa się na granicy epok pogaństwa i chrześcijaństwa, między erą legendową, a erą de facto historycznego biegu czasu. Zarazem jest to moment formowania się polskiego narodu wokół chrześcijańskiego orędzia. Tytułowe postacie obu misteriów podejmują czyn-ofiarę na wzór ofiary Chrystusa i jako władcy wprowadzają Jego Osobę w życie swego ludu. Od tej chwili narodowe dzieje są już częścią historii zbawienia, a zatem uzyskują określony kierunek rozwoju i cel ostateczny, zostają odniesione do sfery wartości cywilizacyjnych i religijnych zarazem. I Wanda, i Krakus ustanawiają w akcie trudnej inicjacji, wymagającej walki z pokusami i złem, wzór kulturowy dla swego narodu, co w finale utworów potwierdzają ich mogiły, tzn. kopce, będące symbolem aktu fundacyjnej ofiary, ostoją zbiorowej pamięci, gwarancją ciągłości narodowych dziejów.

Również Tyrtej-Za kulisami stanowi dzieło doskonale unaoczniające pracę Norwida nad zagadnieniem ,transfiguracji społecznych”. Mamy tu bowiem do czynienia z wyjątkowym nagromadzeniem rozwiązań mieszczących się w tej sferze zagadnień, przy czym dotyczy to najpierw wzajemnej relacji między obydwoma członami dramatu. Norwid stawiając pytanie o ciągłość cywilizacji, uwypukla w stworzonym obrazie świata antynomiczność epok i kultur. Ostra granica przebiega między kulturą antyczną a dziewiętnastowieczną, żywiołem doryjskim

${ }^{21}$ Michał Głowiński tak pisał o Norwidowskiej paraboli: „Z jednej strony stanowi ona strukturę homologiczną wobec struktury świata, z drugiej zaś - jest jego interpretacją, interpretacją raczej nie pojęciową, ale dowodową, «unaoczniającą»”. Zob. M. GŁowIŃsKI, Norwida wiersze-przypowieści, w: Cyprian Norwid. W 150-lecie urodzin, red. M. Żmigrodzka, Warszawa 1973, s. 79. 
a frygijskim, monumentalną formą tragedii, zachowującą pamięć obrzędowych początków, a dramatem współczesnym, odzwierciedlającym aktualną maskaradę życia. Kulturowy kontrapunkt jest też cechą każdego z członów dzieła. W Tyrte$j u$ przedstawione zostają dwie odmiany cywilizacji greckiej: Ateny i Sparta. Cywilizacja ateńska, żywotna i twórcza, czerpie zdaniem autora $\mathrm{z}$ ofiarnego gestu Kodrusa: „On - kamieniem stał się węgielnym przeobrażenia ludu, i oto głęboka Aten żałoba rozrzewniła się po nim w republikę. Nie nauczał on służby warsztatu jak rzemieślnik tępy i surowy, ale gestem jednym jako mistrz tworzył na wieki!" (DW VI, 58). Natomiast cywilizacja Sparty znajduje się w stanie upadku: „Lud ten cały z-żeleźniat... [...] Już skończyło się wszystko, i bóg tam nic nie tworzy więcej..." (DW VI, 56). Skon obecnego ustroju i kultury Sparty, do którego prowadzą działania Tyrteja, umożliwi powstanie nowej formacji kulturowej ${ }^{22}$, pośrednio utoruje drogę chrześcijaństwu. Natomiast w Za kulisami Norwid konfrontuje różne formy cywilizacji współczesnej: cywilizację ,nominalną” zestawia z wizją cywilizacji, której źródłem i miarą jest prawda. Orędownik tego cywilizacyjnego ideału Omegitt, autor Tyrteja, nie dysponuje już mocą sprawczą bohatera swego dzieła, skazany jest na klęskę we wszystkich obszarach swego życia - jako poeta, człowiek poszukujący miłości i prawdy, potencjalny reformator.

Kleopatra i Cezar to przykład kolejny. Dość skrupulatna rekonstrukcja określonego momentu historycznego zostaje tu sprzężona z kreowaniem rozległej panoramy zmierzchu cywilizacji egipskiej. Podobny upadek ma wkrótce, jak zapowiada umierający Marek Antoniusz, stać się udziałem cywilizacji rzymskiej, którą pochłonie „nowy czas” i ,nowi ludzie” 23 . Jednak sytuacja przedstawiona w tragedii Norwida zdaje się mieć, na zasadzie paraleli i paraboli, jeszcze szerszy zasięg - dotyczy również współczesności poety i obserwowanego przezeń zjawiska wyczerpywania się żywotnych sił obecnej formacji kulturowej. Eksponując kulturowy aspekt świata przedstawionego, autor czyni swą tragedię wykładnią refleksji kulturologicznej i historiozoficznej. Przede wszystkim unaocznia tragizm wybitnych jednostek popadających w kolizję z kulturą swych czasów (dotyczy to tytułowych postaci dramatu) oraz tragizm cywilizacji skazanych na utratę znaczenia i powolną agonię ${ }^{24}$.

22 S. SAWICKI, Norwida walka z forma, Warszawa 1986, s. 127.

${ }^{23}$ Do Hera bohater zwraca się tak: „... ludzie jak ty - wezmą / Przyszłość Imperium... oko moje patrycjalne / W chwilach ważnych i w sferach publicznych bystre jest. / Julius, Pompejus, Brutus niepoziomy! - Kato, / I my, którzyśmy chcieli świata Epopei, / Przeszliśmy i byliśmy!... Czas nowy - chce nowych, / Chce praktycznych... rycerzy..." (DW VI, 406). Podobny wydźwięk ma proroctwo Szechery.

${ }^{24}$ Historycznokulturową interpretację tragedii Norwida przedstawiła Elżbieta ŻWIRKOwSKA, zob. taż, Tragedia kultur. Studium o tragedii historycznej C. K. Norwida „, Kleopatra i Cezar”, Lublin 1991. 
Przywołane utwory ukazują, jak specyficzny jest świat przedstawiony Norwidowej dramaturgii i jak bliski widowiskom kulturowym, bo w swej istocie skoncentrowany na prezentacji i interpretacji takich zjawisk, jak zmiany społeczne, transformacje i konfrontacje kultur, ciągłość cywilizacji, cywilizacyjne aspekty istnienia jednostek itd. Do rozwijania tej analogii zachęca również „wpisane” w dzieła Norwida przeświadczenie o dramatycznym charakterze procesów społecznych, które autor ujmuje w ramy akcji zogniskowanej wokół sytuacji kryzysu, rozbicia spójności świata, poważenia ładu społecznego i moralnego, by prowadzić ją następnie w stronę finalnej restytucji ładu na nowych zasadach lub pogłębienia sytuacji kryzysowej. Wydaje się więc, że forma scalająca dramat sceniczny i dramat społeczny jest z punktu widzenia celów Norwida optymalnym rozwiązaniem.

Jednak jest jeszcze jedna kwestia, niezwykle istotna dla specyfiki Norwidowskiego dramatu „transfiguracji społecznych”. Otóż autor, co nie może ujść naszej uwadze, wykazuje szczególne zainteresowanie zachowaniami społecznymi o charakterze obrzędowym. Dlaczego? Z jednej strony jest przekonany, świadczą o tym jego wypowiedzi programowe, że dramat pochodzi z obrzędu i może być jego funkcjonalnym odpowiednikiem. $Z$ drugiej zaś, znajomość różnych historycznych postaci obrzędów łączy, jak można mniemać, ze współczesną sobie antropologiczną refleksją nad formami i społecznymi funkcjami rytuału ${ }^{25}$. W II połowie XIX wieku badania tego typu były już prowadzone, a ich ukoronowaniem stało się przełomowe dla naukowej refleksji nad obrzędem dzieło Arnolda van Gennepa Les rites de passage, wydane w 1909 roku. Francusko-flamandzki etnograf ukazał w nim specyficzną strukturę działań obrzędowych, a mianowicie opisał i zinterpretował obrzędy przejścia, towarzyszące sytuacji zmiany statusu społecznego jednostki i szerzej: sytuacji zmiany społecznej w ogóle ${ }^{26}$. Od-

${ }^{25}$ Zwłaszcza notatnikowe zapiski Norwida mogłyby dostarczyć ciekawego materiału do dalszych badań.

${ }^{26}$ W swym opisie van Gennep wyodrębnił, z punktu widzenia strukturalno-społecznego, trzy zasadnicze elementy obrzędów przejścia: rites de separation - rytuały wyłączenia, rites de marge - rytuały marginalności, przejścia, rites de agregation - rytuały włączenia (zob. A. von GENNEP, Obrzędy przejścia, tłum. B. Biały, Warszawa 2006). Współczesna definicja obrzędów przejścia, niemal tożsama z definicją van Gennepa, zakłada, że są to obrzędy, które: „zaznaczają przejścia osoby przez cykl życiowy, z jednego stopnia do następnego na przestrzeni czasu, z jednej roli lub pozycji społecznej do drugiej, integrujące przy tym doświadczenie ludzkie i kulturowe z przeznaczeniem biologicznym: narodzinami, reprodukcją i śmiercią" (zob. B. MYERHOFF, L. A. CAMINO, V. TURner, Rites of Passage, w: The Encyclopaedia of Religion, ed. M. Eliade, New York 1987, vol. 12, s. 380). Turner, nawiązując do myśli van Gennepa, wyróżnił w obrzędowym przejściu z jednego stanu społecznego (układ postaw, ról, zasad i grup społecznych) do stanu drugiego trzy fazy: preliminarną, liminalną, postliminalną. Jak widać, skupiał uwagę na aspekcie czasowo-przestrzennym rytuału, eksponował zarówno jego potencjał twórczy (dotyczy to zwłaszcza fazy 
notujmy, że dzieło van Gennepa znalazło i krytyków, i kontynuatorów. Ale wśród kontynuatorów, co istotne, pojawili się właśnie teoretycy widowiska kulturowego, m. in. Victor Turner, uznający obrzęd, w tym zwłaszcza obrzędy przejścia, za jeden z gatunków widowisk ${ }^{27}$.

W dramaturgii Norwida mamy do czynienia z wprost uderzającym nagromadzeniem nawiązań do rozmaitych obrzędów, zróżnicowanych pod względem kulturowej genezy i światopoglądowego zaplecza. Stanowią one niejednokrotnie nadrzędny plan utworu dramatycznego, przy czym są zarówno obiektami scenicznego przedstawienia, jak i tworzą wewnętrzną przestrzeń dramatu. Zawsze jednak ich obecność nadaje dramatowi charakter widowiska rytualnego, „naznacza” go rytuałem przynajmniej w pewnym stopniu. Dość przypomnieć, że Norwid czyni integralną częścią swego dramatu obrzędy ofiarne (taki charakter ma ofiara tytułowych bohaterów Zwolona, Wandy, Krakusa), obrzędy inicjacyjne (uczestnikami chrześcijańskiej inicjacji są Wanda w akcie widzenia Boga oraz Krakus podczas spotkania z Progiem i snu w grocie szmaragdowej, doświadczenie inicjacyjne jest też udziałem Tyrteja - wybranka delfickiej wyroczni i natchnionego poety), obrzędy pogrzebowe i żałobne (pogrzeb Kraka w Krakusie, egipski kult zmarłych w Kleopatrze i Cezarze), obrzędy upamiętniające (sceny powstawania kopców w Wandzie i Krakusie), obrzędy weselne (,,wesele-królewskie” w Kleopatrze i Cezarze), obrzędy świąteczne (bal maskowy, nawiązania do karnawału w Za kulisami) ${ }^{28}$.

Rytuał w swych różnych wariantach staje się w dramaturgii Norwida elementem języka „transfiguracji społecznych”. Obrazowanie i tok szeroko rozumianej zmiany społecznej i kulturowej pozostają tu w związku ze scenariuszem obrzędów przejścia, będących podłożem i strukturalną ramą Norwidowskich rytuałów. Tym samym pełnią one kluczową funkcję w kształtowaniu formy i semantycznej spójności poszczególnych utworów. Jak wszystkie rytuały, także i te mają ogromny potencjał poznawczy, symbolicznie odzwierciedlają bowiem model uniwersum, społeczne wyobrażenia i przeświadczenia, kierunek pożądanej transformacji jednostkowej i zbiorowej, drogę wiodącą do sakralnych podstaw istnienia, do obco-

liminalnej), jak i rolę w podtrzymywaniu porządku społecznego i społecznej ciągłości (zob. tegoż, The Ritual Process: Structure and Anti-structure, Chicago 1969). Zob. też: M. BuchowsKi, Magia i rytuat, Warszawa 1993, s. 132-140.

${ }^{27}$ Typologia widowisk to przedmiot ożywionych dyskusji, jednak gra, obrzęd, święto i spektakl są najczęściej wskazywane jako odrębne gatunki widowiska kulturowego. Zob. J. J. MACALOON, s. 28-29.

${ }^{28}$ Każdy z rytuałów przedstawionych przez Norwida wymaga z pewnością dalszej szczegółowej interpretacji. O obrzędowej stronie Zwolona, Wandy, Krakusa, Tyrteja-Za kulisami pisałam w swych wcześniejszych pracach poświęconych Norwidowej dramaturgii. 
wania ze światem nadprzyrodzonym i z samym bóstwem ${ }^{29}$. Jednak zauważmy, że wprowadzenie rytuału w obręb dramatu ma ogromny wpływ również na komunikacyjny i performatywny wymiar formy dramatycznej. Za pośrednictwem rytuału dramaturg może nawiązać głęboką więź z odbiorcą, może komunikować mu fundamentalne prawdy o świecie, może go duchowo i moralnie formować, ugruntowywać w nim poczucie wspólnoty powstającej wokół określonych sensów i wartości, czyli wzmacniać więź społeczną. Odbiorca dramatu ma zatem szansę stać się uczestnikiem obrzędu, jest w stanie doświadczyć rytualnej przemiany. I trzeba przyznać, że Norwid skwapliwie korzysta z możliwości, jakie stwarza opisana powyżej sytuacja. Ożywia w ten sposób pamięć o początkach dramatu, reaktualizuje jego rolę ,świętą, budująca, religijną", otwiera scenę na żywe relacje z publicznością, czyni twórczość dramatyczno-teatralną potencjalnym organem paidei i źródłem (samo) poznania - dla uczestników widowiska.

Należy podkreślić, że przedmiotem zainteresowania Norwida są też rytuały zdesakralizowane, ograniczone do społecznych ceremonii, czyli do praktyk zbiorowych o charakterze działań steatralizowanych, które pozostają jednak w pewnej relacji do właściwego obrzędu ${ }^{30}$. W Norwidowskich dramatach są to przede wszystkim rytuały codziennych kontaktów międzyludzkich, czyli rytuały interakcyjne ${ }^{31}$, związane z kulturą salonu, z etykietą towarzyszącą salonowemu spotkaniu i salonowej konwersacji, oraz z miłosnymi kontaktami interpersonalnymi ${ }^{32}$ (Za kulisami, Pierścień

${ }^{29} \mathrm{~W}$ trakcie rytuału dochodzi do komunikowania najgłębszych wartości danego społeczeństwa, podstawowych zasad, rzeczy odwiecznych i najbardziej uświęconych. A zatem można powiedzieć, że „chrześcijańska drama”, naukowo opisana przez Irenę Sławińską, stanowi w dramaturgii Norwida „wewnętrzny rdzeń” rytualnych działań. Procesy kulturowe, społeczne i międzyludzkie poeta postrzega i ocenia zawsze z perspektywy chrześcijańskiej, z punktu widzenia celów nadprzyrodzonych chrześcijaństwa, ale także jego dziejów i dziewiętnastowiecznych potrzeb.

${ }^{30}$ Zob. J. Maisonneuve, Rytualy dawne i współczesne, przeł. M. Mroczek, Gdańsk 1995, s. 11. Antropolodzy mówią również o ceremoniach przejścia: „Z c e r e m o n i ą p r z e j ś c i a mamy do czynienia wówczas, gdy moc podejmowanych działań obrzędowych ogranicza się do ich skutków performatywnych opartych o ustanowione konwencje społeczno-kulturowe, polegające wyłącznie na transgresji jednostek, pozbawione przy tym implikacji pozakomunikacyjnych". Natomiast performatywna moc rytuału przejścia obejmuje zarazem transformację (zmiany substancjalne) i transgresję (zmiana statusu społecznego). Zob. M. BucHOWsKI, s. 141.

31 Jest to termin Ervinga Goffmana, zaczerpnięty z jego słynnej książki Interaction Ritual (1967), poświęconej analizie rytualnych aspektów interakcji społecznej (zob. E. GoFFMANN, $R y$ tuat interakcyjny, przeł. A. Szulżycka, Warszawa 2006).

32 Te ważne dla dramaturgii Norwida zagadnienia niejednokrotnie rozpatrywano w kategoriach klasycznej poetyki dramatu. Zob. np. I. SŁAWIŃsKA, O komediach Norwida, Lublin 1953; I. SŁAwIŃSKA, ,, Ciag scenicznych gestów”, w: taż, Reżyserska ręka Norwida, Kraków 1971; J. ZACH-BŁoŃsKA, Monolog różnogłosy. O dramatach współczesnych Cypriana Norwida, Kraków 1993. 
Wielkiej-Damy, Miłość-czysta u kąieli morskich). Nacisk kładziony przez Norwida na tę formę rytuałów ma związek z kreowaniem przezeń obrazu cywilizacji „kupieckiej i przemysłowej”, dla której charakterystyczna jest redukcja domeny symboliczno-obrzędowej i konwencjonalizacja aktów rytualnych. Efektem postępującej desakralizacji świata są zatem rytuały niepełne, pozorne, puste, w sensie religijnym, metafizycznym, egzystencjalnym - nieskuteczne. Za kulisami, Pierścień Wielkiej-Damy, Mitość-czysta u kapieli morskich to dramaty Norwida świetnie obrazujące ten problem, zwłaszcza na poziomie rytuałów związanych z zaręczynami i małżeństwem (pary Omegitt - Lia, Mak-Yks - Hrabina Harrys mają jednak przeciwwagę w bohaterach zdolnych do głębokiego przeżywania miłości, takich jak Tyrtej i Eginea oraz Szeliga i Magdalena). Z kolei Aktor unaocznia konwencjonalizację teatralnych rytuałów, łącząc to zjawisko z ogólną charakterystyką teatru życia społecznego, z powszechnym aktorstwem i zatratą autentyczności (Jerzy przekracza jednak granice tak rozumianego teatru, dosięgając w swym życiu teatru - ,atrium spraw niebieskich"; DW V, 391). Z podobnym zakresem problemów mamy do czynienia w Za kulisami (sceny współczesnej maskarady, obrazujące teatralizację życia społecznego, zostają wartościująco skonfrontowane z podniosłą obrzędowością starożytnego teatru, a „wyświstany” dramaturg Omegitt sam porównuje się z Tyrtejem, poetą wtajemniczonym w sferę sacrum), choć tu dodatkowo Norwid czyni puste rytuały również formą wyrazu politycznej opresji i stanu zbiorowego zniewolenia (aluzje do realiów warszawskich). Natomiast Kleopatra i Cezar zawiera obraz o najszerszym, jak się wydaje, polu odniesień, bo jest to obraz cywilizacji (egipskiej) pogrążonej w upadku, którego głównym wyznacznikiem okazuje się wszechogarniająca ceremonializacja życia społecznego. To zarazem obraz najbardziej pesymistyczny w dramaturgii Norwida, gdyż w świecie przedstawionym tragedii nie znajdujemy jednoznacznie pozytywnego kontrapunktu dla tej waloryzacji. Tu ceremonie ostatecznie pochłaniają obrzędy przejścia, dające dostęp do sakralnych źródeł życia i nadzieję na jego trwanie oraz pozytywny rozwój.

Analizowane powyżej przykłady, potwierdzając generalną tezę o wyjątkowej funkcji rytuałów w świecie przedstawionym utworów dramatycznych Norwida, dobrze unaoczniają też funkcjonalną i semantyczną rozpiętość zabiegu rytualizacji dramatu. Poeta, jak widać, różnicuje rytuały i ceremonie, a rozróżnienie to odgrywa istotną rolę $\mathrm{w}$ jego obrazowaniu przebiegu procesów społecznych i kulturowych w momencie kryzysowym. Norwid doskonale zdaje sobie sprawę z tego, że obrzędy przejścia tracą pierwotne znaczenie w podlegającym sekularyzacji świecie. Tak więc bohaterowie jego współczesnych, zwłaszcza późnych dramatów nie mogą już dokonać zmiany swego statusu społecznego wedle obrzędowego scenariusza. Pozostaje im jedynie pamięć obrzędowego, sakralnego wymiaru życia jako kryterium oceny świata współczesnego - to przypadek Omegitta czy Mak-Yksa. 
Człowieka XIX stulecia coraz częściej satysfakcjonują bowiem, jak sądzi pisarz, powierzchowne, świeckie ceremonie, co najlepiej unaocznia mentalność i działania ludzi typu Durejków. Ale w sumie oznacza to, że problem rytualizacji dramatu ściśle łączy się z kluczowymi Norwidowskimi pytaniami o kondycję dziewiętnastowiecznego człowieka i przyszłość cywilizacji.

Podsumujmy. Wiek XIX, diagnozowany przez Norwida jako moment społecznego kryzysu, naruszenia tradycyjnego ładu, starcia różnych formacji kultury w świecie zewnętrznym i w świadomości człowieka, koniecznie wymaga nowego dramatu - na miarę problemów epoki. Niewątpliwie dramaturgia osnuta wokół idei „transfiguracji społecznych" może być adekwatną odpowiedzią na wyzwania czasu - stanowi oryginalną formę artystycznej reprezentacji sił działających w przestrzeni ludzkiego życia i sprawne narzędzie ich rozumienia w duchu antropologii społecznej. Co więcej, pozwala autorowi na kultywowanie odwiecznych obrzędowych funkcji twórczości dramatyczno-teatralnej i na udział, za pośrednictwem dramatu jako widowiska kulturowego, w procesie formowania człowieka i przeobrażania cywilizacji z myślą o „społeczności obiecanej”. Można przypuszczać, iż na tym właśnie polega według Norwida socjalna godność i misja poety-dramaturga w czasach społecznej zmiany, w czasach przejścia.

\section{BIBLIOGRAFIA}

Antropologia widowisk. Zagadnienia i wybór tekstów, oprac. A. Chałupnik, W. Dudzik, M. Kanabrodzki, L. Kolankiewicz, wstęp i red. L. Kolankiewicz, Warszawa 2005.

Bавсоск B. A.,, Reflexivity: Definitions and Discriminations, w: Signs about Signs. The Semiotics of Self-References, ed. B. A. Babcock, New York 1980.

Buchowski M., Magia i rytuat, Warszawa 1993.

DunAJSKI A., Chrześcijańska interpretacja dziejów w pismach Cypriana Norwida, Lublin 1985.

Feliksiak E., Norwid i Vico, „Przegląd Humanistyczny” 1968, nr 3.

Gennep van A., Rites de passage, Paris 1909.

Goffmann E., Rytuat interakcyjny, przeł. A. Szulżycka, Warszawa 2006.

HaŁas E., Interakcjonizm symboliczny. Społeczny kontekst znaczeń, Warszawa 2006.

Maisonneuve J., Rytuały dawne i współczesne, przeł. M. Mroczek, Gdańsk 1995.

Myerhoff B., Camino L. A., Turner V., Rites of Passage, w: Encyclopaedia of Religion, ed. M. Eliade, New York 1987, vol. 12.

Rytuat, dramat, święto, spektakl. Wstęp do teorii widowiska kulturowego, red. J. J. MacAloon, przeł. K. Przyłuska-Urbanowicz, Warszawa 2009.

SAWICKI S., Norwida walka z forma, Warszawa 1986. 
SCHeChNeR R. Collective Reflexivity: Restoration of Behavior, w: A Crack in the Mirror: Reflexive Perspectives in Anthropology, eds. B. Myerhoff, J. Ruby, Philadelphia 1982.

SŁawińska I., O komediach Norwida, Lublin 1953.

SŁAwiŃsKa I., Reżyserska ręka Norwida, Kraków 1971.

SŁAwIŃSKA I., ,, Chrześcijańska drama” Norwida, „Studia Norwidiana” 3-4: 1985-1986.

ŚwiOnTeK S., Norwidowski teatr świata, Łódź 1985.

Turner V., Schism and Continuity in an African Society, Manchester 1957.

Turner V., The Ritual Process: Sturcture and Anti-Structure, Chicago 1969.

Turner V., Teatr w codzienności, codzienność w teatrze, przeł. P. Skurowski, „Dialog” 1988, nr 9.

TURner V., Gry społeczne, pola i metafory. Symboliczne działanie w społeczeństwie, przeł. W. Usakiewicz, Kraków 2005.

ZaCh-BŁońska J., Monolog różnogłosy. O dramatach współczesnych Cypriana Norwida, Kraków 1993.

ZıoŁowicz A., Norwidowski dramat wieloperspektywiczny, w: TAŻ, Dramat i romantyczne „Ja”. Studium podmiotowości w dramaturgii polskiej doby romantyzmu, Kraków 2002.

ZıoŁowicz A., Między starożytnościa a współczesnościa. Formy tragedii w twórczości Cypriana Norwida, w:Dlugie trwanie. Różne oblicza klasycyzmu, red. R. Dąbrowski i B. Dopart, Kraków 2011.

Żwirkowska E., Tragedia kultur. Studium o tragedii historycznej C. K. Norwida „, Kleopatra i Cezar”, Lublin 1991.

\section{NORWIDOWSKI DRAMAT „TRANSFIGURACJI SPOŁECZNYCH”}

\section{Streszczenie}

Artykuł zawiera rozważania na temat Norwidowskiej koncepcji dramatu i teatru, zakładającej ich ścisły związek z życiem społecznym i jego historycznymi przemianami. Analizy wypowiedzi metadramatycznych i metateatralnych poety, czyli przede wszystkim szkicu Widowiska w ogóle uważane, Białych kwiatów, fragmentów wykładów O Juliuszu Słowackim oraz przedmowy do Pierścienia Wielkiej-Damy,dostarczają szeregu argumentów na rzecz tezy o intencjonalnym kształtowaniu przez Norwida dramaturgii osnutej wokół idei „transfiguracji społecznych". Co więcej, charakter jego dorobku dramatopisarskiego pozwala na zastosowanie w interpretacji poszczególnych dziełantropologiczno-socjologicznych kategorii dramatu społecznego i widowiska kulturowego.Większość utworów dramatycznych Norwida unaocznia bowiem sytuację przemiany społecznej, ujętej w ramy obrzędów przejścia i steatralizowanych praktyk społecznych (społeczne ceremonie, rytuały interakcyjne). Dzięki temu Norwidowski dramat staje się artystyczną reprezentacją sił działających w przestrzeni życia zbiorowego, narzędziem ich rozumienia w duchu antropologii społecznej, a także ważnym czynnikiem formowania człowieka.

Słowa kluczowe: Cyprian Norwid;estetyka dramatu;dramat społeczny; widowisko kulturowe; obrzędy przejścia 


\title{
NORWID'S DRAMA OF “SOCIAL TRANSFIGURATIONS”
}

\begin{abstract}
The article discusses Norwid's concept of drama and theatre; notably, he assumes their close relationship with social life and its historical changes. Basing on analyses of meta-dramatic and meta-theatrical statements made by the poet, contained primarily in the essays "Widowiska w ogóle uważane" and "Białe kwiaty" [Performances considered in general; White flowers], in passages from lectures on Słowacki (O Juliuszu Stowackim), and in the introduction to Pierścien Wielkiej-Damy [The Ring of a Great Lady], it is possible to formulate the thesis that Norwid intentionally developed a vision of drama based on the idea of "social transfigurations."What is more, the character of his dramatic works enables one to interpret his particular theatrical pieces in the light of anthropological and sociological categories of social drama and cultural performance. After all, most of Norwid's dramatic works depict situations of social change in terms of rites of passage and theatricalized social practices, e.g. social ceremonies or ritualized interactions. As a result, Norwidian drama becomes an artistic representation of forces shaping collective life, a lens facilitating their understanding in the spirit of social anthropology, and an important factor in the formation of man.
\end{abstract}

Translated by Grzegorz Czemiel

Key words: Cyprian Norwid, aesthetics of drama, social drama, cultural performance, rites of passage

AgnieszKa ZıoŁowicz - prof. dr hab., pracownik Katedry Historii Literatury Oświecenia i Romantyzmu na Wydziale Polonistyki Uniwersytetu Jagiellońskiego. Główne obszary badań: historia literatury romantyzmu i postromantyzmu; dramaturgia wieku XIX; estetyczne i antropologiczne konteksty literatury dziewiętnastowiecznej. Autorka publikacji książkowych (Misteria polskie. Z problemów misteryjności w polskim dramacie romantycznym i modernistycznym; Dramat i romantyczne ,Ja”. Studium podmiotowości w dramaturgii polskiej epoki romantyzmu; Poszukiwanie wspólnoty. Estetyka dramatyczności a więź międzyludzka w literaturze epoki romantyzmu (preliminaria), Komedia dworkowa, Eklektyzmy, synkretyzmy, uniwersa. $Z$ estetyki dzieła epoki oświecenia i romantyzmu) oraz artykułów naukowych i edycji tekstów źródłowych. 